\title{
ACUTE CHANGES IN RENAL EXCRETION OF WATER AND SOLUTE IN PATIENTS WITH LAENNEC'S CIRRHOSIS, INDUCED BY THE ADMINISTRATION OF THE PRESSOR AMINE, METARAMINOL *
}

\author{
By DANIEL L. GORNEL, RUBEN G. LANCESTREMERE, $\nmid$ SOLOMON PAPPER AND \\ LEAH M. LOWENSTEIN
}

(From the Medical Service and the Research Laboratory, Boston Veterans Administration

Hospital, and the Departments of Medicine, Boston University School of Medicine, Tufts University School of Medicine, Boston, Mass., and the Medical College of Virginia, Richmond, Va.)

(Submitted for publication July 25, 1961 ; accepted October 9, 1961)

Studies in cirrhotic patients dying with azotemia suggested that the oliguria and nitrogen retention might be secondary to altered renal hemodynamics rather than to any parenchymal renal lesion (1-3). Further inquiry demonstrated that the observed reduction in glomerular filtration rate (GFR) and renal plasma flow, under these conditions, was not attributable to diminished cardiac output, but rather occurred in the face of an increased cardiac output (4). Diminished GFR and renal plasma flow when cardiac output is increased suggests a decrease in extrarenal peripheral resistance with or without an increase in renal resistance (5) or circulatory shunting of some of the nephrons.

In view of these observations it was decided to determine in patients with cirrhosis the effects on fluid and electrolyte excretion of an agent known to have vasopressor and vasoconstrictor properties. It was considered desirable to include patients who had cirrhosis with normal as well as reduced GFR and renal plasma flow, and to study patients with and without impaired water diuresis. Metaraminol (Aramine) was the agent employed.

The present report demonstrates that metaraminol produces an increased excretion of water,

* This Investigation was supported in part by Research Grant N.I.H.-H-5162 from the National Heart Institute; by Grant 380-F from the Massachusetts Heart Association; and by the Roanoke Valley Heart Association. Presented in part at the Annual Session of the American College of Physicians, May 11, 1961.

+ This work was done in part during the tenure of a research fellowship of the American Heart Association, at Medical College of Virginia, Richmond, Va. Formerly Research Fellow of the Massachusetts Heart Association, Tufts Univ. School of Medicine. total solute, sodium, and potassium in patients with Laennec's cirrhosis. The drug similarly employed in patients without liver disease failed to evoke consistent changes.

The mechanism of this effect of metaraminol on renal excretion is not clear, although the data are consistent with the thesis that the observed changes are of circulatory origin.

\section{METHODS}

Nineteen studies were performed on 16 volunteers suffering from decompensated Laennec's cirrhosis. All had ascites, and many had edema of the legs. They had no known history of previous renal disease, and none had albuminuria or pyuria. Two, W.F. and A.R., had essential hypertension without cardiomegaly or evidence of renal disease. None had gastrointestinal bleeding great enough to cause a fall in hematocrit or blood pressure, although occasional guaiac-positive (trace or $1+$ ) stools were noted in 4 subjects. During at least 4 days prior to study the subjects were provided a diet containing either 10 or $25 \mathrm{mEq}$ of sodium daily. For comparison, five studies were performed on 4 patients without liver disease. These subjects were convalescents who had no evidence of renal, cardiac, or hepatic disease. Two were given a diet containing $25 \mathrm{mEq}$ of sodium daily for 5 days prior to study. No dietary restrictions were imposed on the other two comparison subjects.

On the day of the study the subjects ate their usual breakfast at 8 a.m. Shortly thereafter they were given a water load of $20 \mathrm{ml}$ per $\mathrm{kg}$ body weight, partly as tap water orally and partly as a 4 to 5 per cent hexose solution intravenously. Generally, the sicker the patient, the larger was the proportion of the water load given intravenously. The water lost as urine or estimated insensible loss during the study was replaced either orally or intravenously. Urine was collected at intervals of 10 to 30 minutes. Indwelling catheters were placed in the bladders of Patients J.K., R.T., and A.B. The bladders of these patients were washed with air after each collection period. 
After the urine flow became constant-usually 1.5 hours after the water load was administered-control collection periods were obtained. In 17 studies metaraminol was then infused intravenously as a $10 \mathrm{mg}$ per $100 \mathrm{ml}$ solution in 5 per cent dextrose at a rate that raised the mean blood pressure of each patient an average of 25 $\mathrm{mm} \mathrm{Hg}$ above the pre-metaraminol periods. Blood pressure determinations were made every 2 to 7 minutes, and the rate of the metaraminol infusion was adjusted to maintain a relatively stable blood pressure in the desired range. The metaraminol infusion was maintained for as long as 153 minutes. In 6 subjects urine collections were made for three to four periods after the cessation of the metaraminol infusion. Throughout the study the patients remained supine except when they stood to void. They did not smoke. One subject with cirrhosis was given $7 \mathrm{mg}$ of metaraminol by intramuscular injections; another received $25 \mathrm{mg}$ of the drug orally. Venous blood samples were obtained from an indwelling needle with fitted stylet placed in the arm opposite the infusion. Inulin and para-aminohippurate (PAH) clearances were determined in 8 subjects : J.Ly., E.R., W.M., G.F., J.La., S.H., R.T., and F.M. Urine and blood were analyzed for osmolality with a Fiske osmometer; for sodium and potassium with a Baird Atomic flame photometer employing an internal standard; for creatinine by the $\mathrm{Pe}-$ ters modification of the Folin method (6) and the method of Hare (7); for inulin by the method of Young and Raisz (8); and for PAH by the method of Goldring and Chasis (9). Inulin, creatinine, PAH, and osmolal clearances were calculated by the conventional formulas (10a) and are expressed as milliliters of plasma cleared per minute, not corrected for body surface area. Free water clearance represents the difference between urine flow and the osmolal clearance per minute. The mean blood pressure was calculated as the diastolic pressure plus onethird of the pulse pressure. Statistical evaluation of the data employed Student's $t$ test; the difference between two groups of results was considered significant if $p=<$ 0.05 .

\section{RESULTS}

\section{Intravenous metaraminol}

For convenience in presentation the subjects with cirrhosis were divided into two groups according to their diuretic response to administered water during the control periods. For

TABLE I

Clinical characteristics and laboratory findings in the experimental subjects

\begin{tabular}{|c|c|c|c|c|c|c|c|c|}
\hline Subject & Age & Ascites & $\underset{\text { tocrit }}{\text { Hema- }}$ & $\begin{array}{c}\text { Total } \\
\text { bilirubin }\end{array}$ & $\underset{\text { creatinine }}{\text { Serum }}$ & $\begin{array}{c}\text { Serum } \\
\text { albumin }\end{array}$ & $\begin{array}{l}\text { Serum } \\
\text { osmolal.* }\end{array}$ & $\underset{\text { sodium* }}{\text { Serum }}$ \\
\hline & $y r s$ & & $\%$ & $m g / 100 m l$ & $m g / 100 m l$ & $\mathrm{~g} / 100 \mathrm{ml}$ & $\underset{\mathrm{H}_{2} \mathrm{O}}{m \mathrm{O}_{\mathrm{sm}} / \mathrm{kg}}$ & $m E q / L$ \\
\hline \multicolumn{9}{|c|}{ Without liver disease } \\
\hline $\begin{array}{l}\text { J.Ly. } \\
\text { E.R. } \\
\text { W.M. } \\
\text { A.U. }\end{array}$ & $\begin{array}{l}34 \\
32 \\
32 \\
51\end{array}$ & $\begin{array}{l}0 \\
0 \\
0 \\
0\end{array}$ & $\begin{array}{l}47 \\
46 \\
42 \\
46\end{array}$ & & $\begin{array}{l}0.70 \\
0.94 \\
0.95 \\
1.05\end{array}$ & & $\begin{array}{l}271 \\
271 \\
270 \\
280\end{array}$ & $\begin{array}{l}135 \\
130 \\
134 \\
136\end{array}$ \\
\hline \multicolumn{9}{|c|}{ Cirrhosis with normal water diuresis (group I) $\dagger$} \\
\hline $\begin{array}{l}\text { G.F. } \\
\text { W.F. } \\
\text { J.K. } \\
\text { E.B. } \\
\text { A.R. } \\
\text { W.P. }\end{array}$ & $\begin{array}{l}35 \\
58 \\
69 \\
35 \\
40 \\
67\end{array}$ & $\begin{array}{l}\text { mod. } \\
\text { mod. } \\
\text { mod. } \\
\text { marked } \\
\text { marked } \\
\text { mod. }\end{array}$ & $\begin{array}{l}40 \\
45 \\
34 \\
40 \\
48 \\
40\end{array}$ & $\begin{array}{l}1.8 \\
0.6 \\
2.8 \\
3.6 \\
2.0 \\
0.6\end{array}$ & $\begin{array}{l}0.65 \\
0.80 \\
0.64 \\
0.65 \\
0.73 \\
0.84\end{array}$ & $\begin{array}{l}2.7 \\
3.9 \\
2.8 \\
2.6 \\
3.7 \\
2.4\end{array}$ & $\begin{array}{l}264 \\
280 \\
274 \\
264 \\
254 \\
275\end{array}$ & $\begin{array}{l}132 \\
134 \\
135 \\
134 \\
128 \\
139\end{array}$ \\
\hline \multicolumn{9}{|c|}{$\begin{array}{l}\text { Cirrhosis with abnormal water diuresis (group II) } \dagger \\
\text { Normal or slightly reduced GFR (IIA) }\end{array}$} \\
\hline $\begin{array}{l}\text { R.C. } \\
\text { J.G. } \\
\text { J.La. } \\
\text { S.H. } \\
\text { J.C. } \\
\text { R.T. }\end{array}$ & $\begin{array}{l}60 \\
55 \\
70 \\
45 \\
48 \\
42\end{array}$ & $\begin{array}{l}\text { mod. } \\
\text { mod. } \\
\text { mod. } \\
\text { marked } \\
\text { marked } \\
\text { marked }\end{array}$ & $\begin{array}{l}28 \\
44 \\
41 \\
32 \\
29 \\
37\end{array}$ & $\begin{array}{l}3.0 \\
3.4 \\
1.0 \\
4.8 \\
2.0 \\
1.4\end{array}$ & $\begin{array}{l}0.87 \\
0.68 \\
0.65 \\
0.42 \\
0.48 \\
0.50\end{array}$ & $\begin{array}{l}3.6 \\
2.2 \\
2.1 \\
2.3 \\
2.6 \\
2.9\end{array}$ & $\begin{array}{l}276 \\
268 \\
258 \\
249 \\
258 \\
261\end{array}$ & $\begin{array}{l}134 \\
131 \\
130 \\
128 \\
128 \\
129\end{array}$ \\
\hline \multicolumn{9}{|c|}{ Markedly reduced GFR (IIB) } \\
\hline $\begin{array}{l}\text { F.M. } \\
\text { A.B. } \\
\text { R.C. } 8\end{array}$ & $\begin{array}{l}63 \\
64 \\
60\end{array}$ & $\begin{array}{l}\text { mod. } \\
\text { marked } \\
\text { marked }\end{array}$ & $\begin{array}{l}36 \\
29 \\
32\end{array}$ & $\begin{array}{r}2.4 \\
2.8 \\
13.2\end{array}$ & $\begin{array}{l}1.80 \\
1.76 \\
1.01\end{array}$ & $\begin{array}{l}2.6 \\
3.0 \\
1.9\end{array}$ & $\begin{array}{l}263 \\
260 \\
262\end{array}$ & $\begin{array}{l}126 \\
122 \\
130\end{array}$ \\
\hline
\end{tabular}

* During water loading.

$\uparrow$ See text for explanation of groups.

† Study performed 5/17/60.

$\S$ Study performed $12 / 29 / 59$. 


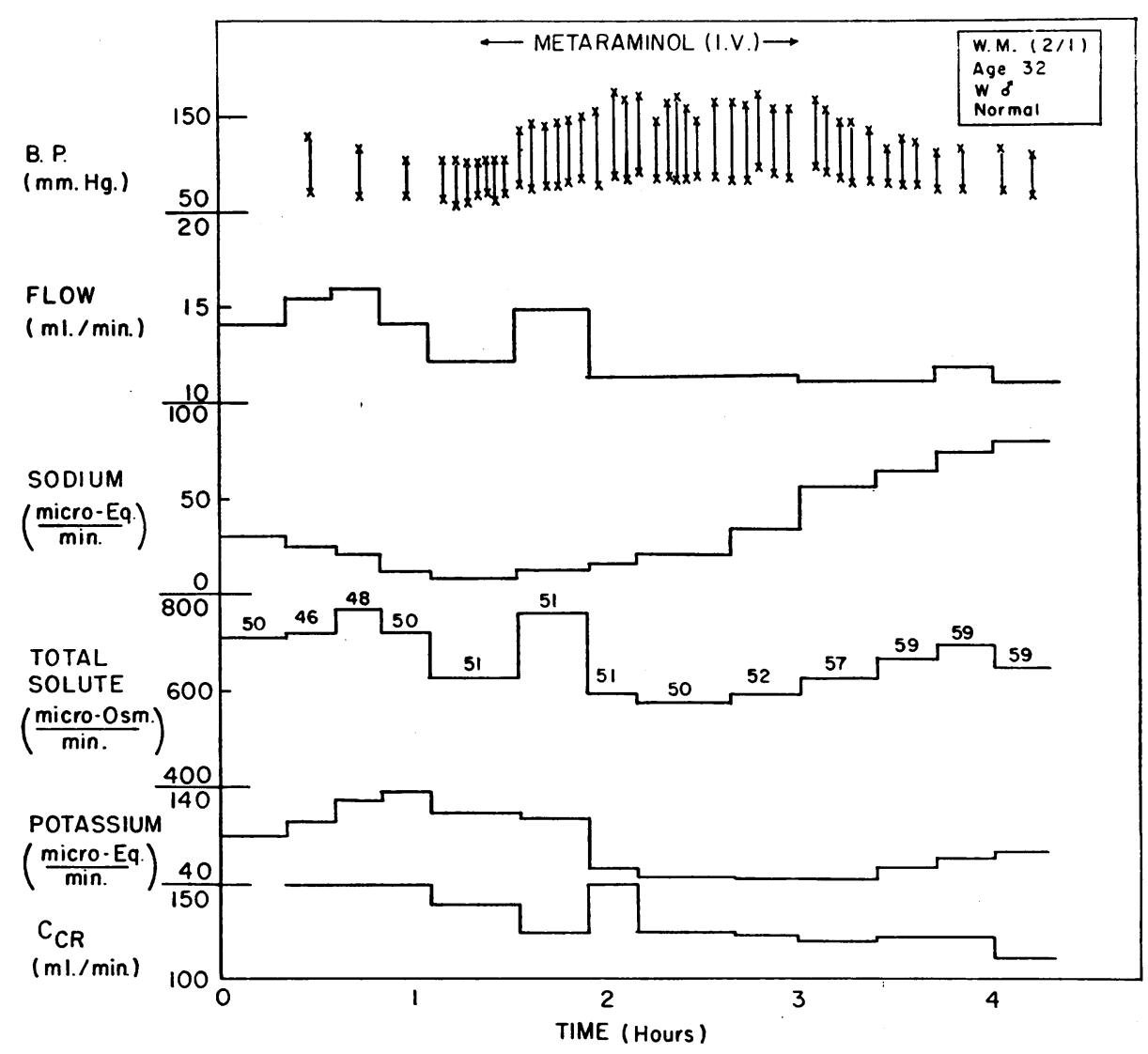

Fig. 1. Infusion of metaraminol in subject without liver disease (W.M.) The number above total solute excretion denotes the urine concentration in $\mathrm{mOsm}$ per $\mathrm{kg}$ of water for each period.

these purposes a normal response was defined as a urine flow of over $7 \mathrm{ml}$ per minute (11) associated with a urine osmolality of under 100 mOsm per $\mathrm{kg}$ (12) following a water load of 20 $\mathrm{ml}$ per $\mathrm{kg}$ body weight. Group I consists of patients with cirrhosis who had a normal response. Group II consists of patients with cirrhosis and an impaired response to the water load; group II is further subdivided according to estimated GFR: IIA with normal or only slightly reduced GFR and IIB with markedly reduced GFR.

Clinical features. Certain clinical characteristics of and laboratory findings in the subjects are listed in Table I. All of the patients with cirrhosis had ascites. Subjects F.M., A.B., and R.C. of group II appeared more ill than the others and had slightly altered levels of consciousness. The subjects of group II also differed from those of group I in that they tended to have slightly lower hematocrits and serum osmolalities. Subjects F.M. and A.B. of group II had decidedly elevated concentrations of creatinine in the serum. The serum bilirubin levels varied in each group. As has been observed before, some of the patients who responded normally to a water load had elevated bilirubin levels (13).

Blood pressure. The mean blood pressures before metaraminol infusion were similar in the comparison subjects and the subjects in groups I and IIA. The mean blood pressures of the subjects in group IIB were significantly lower than the others. During metaraminol infusion the average rise in mean blood pressure was $32 \mathrm{~mm}$ $\mathrm{Hg}$ in the comparison group, 24 in group $\mathrm{I}$, and 24 in group II. A summary of results of the detailed experiments in subjects given metaraminol intravenously is shown in Table II. 
THE EFFECT OF METARAMINOL ON RENAL FUNCTION IN CIRRHOSIS

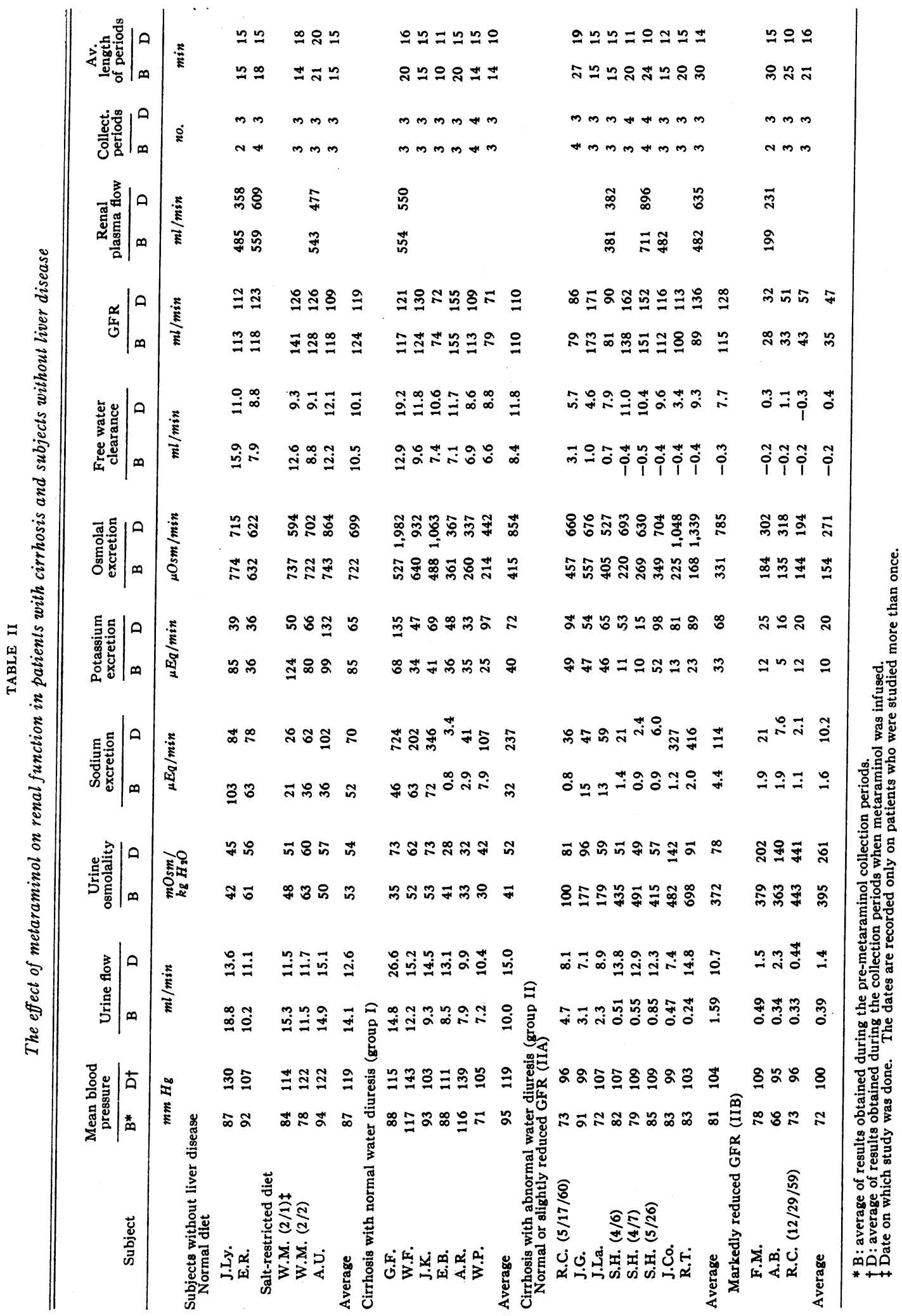


Subjects without liver disease (5 studies on 4 subjects; Table II, Figure 1). All of the subjects of this group had normal diuretic response to administered water. During metaraminol infusion, urine flow fell in two subjects and was unchanged in three. The osmolality was essentially unchanged. Changes in the excretion of sodium, potassium, and total solute were variable. Endogenous creatinine clearance and inulin clearance were relatively unchanged in all but one study, that of W.M. performed on February 1,1960 . (When W.M. was restudied the next day these clearances remained stable.)

Group I. Patients with cirrhosis and a normal diuretic response to administered water ( 6 studies in 6 subjects; Table II, Figure 2). The subjects of this group, like those in the comparison group had normal urine flows and dilute urines after water loading. In each instance metaraminol in- fusion was associated with an increase in urine flow. In four instances this increased rate of urine flow was accompanied by an increase in urine osmolality, while in one study the urine became less concentrated and in one there was no change in osmolality. The rate of sodium excretion increased strikingly in five of the six subjects and only slightly in one. Metaraminol infusion was also associated with notable increase in the rate of excretion of total solutes in five of the six subjects. Potassium excretion increased in five instances. The infusion of metaraminol was not accompanied by any consistent change in endogenous creatinine clearance. The study in Subject E.B. differed from other studies in this group in that the rise in urine flow during the administration of metaraminol was accompanied by a decrease in urine osmolality while sodium excretion remained low.

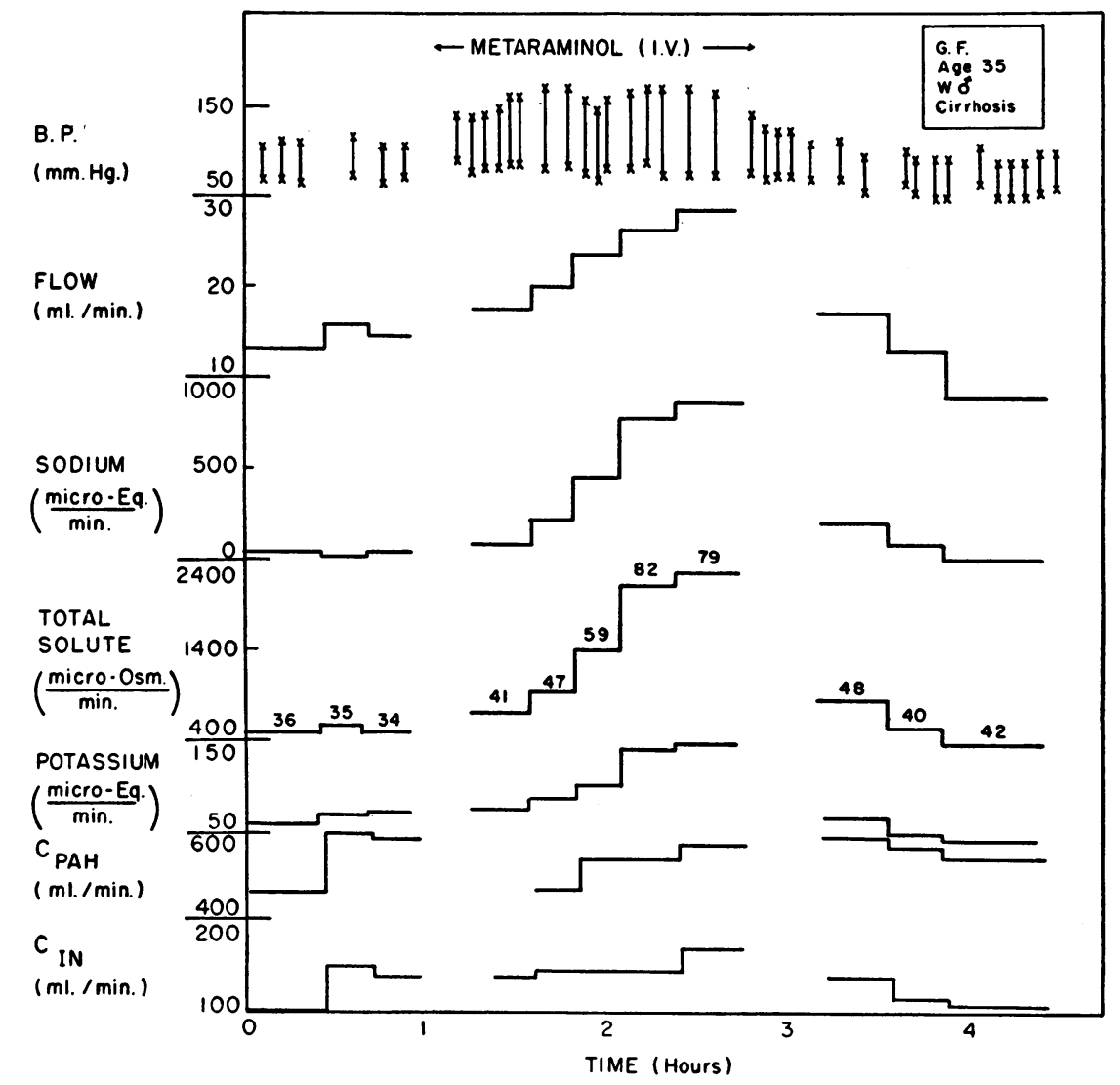

Fig. 2. Infusion of Metaraminol in PATIENT With CIRRHosis, GROUP I (G.F.). Note that ordinate scale differs from other figures. The number above total solute excretion denotes the urine concentration in mOsm per $\mathrm{kg}$ of water for each period. 
Group II. Patients with cirrhosis and impaired response to water loading. The subjects in this group had maximal urine flows of under $5 \mathrm{ml}$ per minute. In five studies the urine flows were under $1 \mathrm{ml}$ per minute. The urine osmolalities were $100 \mathrm{mOsm}$ per $\mathrm{kg}$ or over, and in the subjects with the lower flow rates, the urine failed to become more dilute than plasma. This phenomenon has been noted previously in other cirrhotics (13).

IIA. Normal or slightly reduced GFR (8 studies in 6 subjects; Table II, Figure 3). During metaraminol infusion all of the urine flows increased to more than $7 \mathrm{ml}$ per minute while the urine osmolality of all but one subject (J.C.) declined to less than $100 \mathrm{mOsm}$ per $\mathrm{kg}$. Total solute excretion rose in all subjects. Before the metaraminol infusion the subjects in this group excreted significantly lower amounts of sodium than did the comparison subjects and the subjects in group I. During the metaraminol infusion sodium excretion increased markedly in six of eight subjects to a level comparable with that observed in the patients in both the control and group I subjects.

The subjects who had a negative free water clearance before metaraminol developed a positive free water clearance during the drug administration. Estimated GFR remained unchanged or rose with metaraminol.

IIB. Markedly reduced GFR (3 studies in 3 patients; Table II, Figure 4). When given a water load the subjects of this group excreted small amounts of concentrated urine. During metaraminol the flows increased slightly, and the urine of two of the subjects became dilute. The rates of excretion of sodium and potassium before metaraminol were very low and rose somewhat when the drug was administered; total solute excretion also rose. In all three subjects the low values for GFR, estimated as inulin or creatinine clearance, rose during metaraminol infusion. While the exact magnitude of the rise in clearance cannot be stated with confidence because of the "dead space" errors imposed by changing rates of urine flow, there are sufficient collection periods at the higher rates of flow to suggest that there was some definite increase in creatinine clearance (Figure 4). Subject R.C., who responded minimally to metaraminol, im-



Fig. 3. Infusion of MEtaraminol in PATIENT With CIRRHOSIS, GROUP IIA (J.LA.). Note that ordinate scale differs from other figures. The number above total solute excretion denotes the urine concentration in mOsm per $\mathrm{kg}$ of water for each period.

proved clinically over the next 5 months, although he still had marked ascites. When he was retested, his response to water loading had improved to such an extent that he was placed in group I (R.C., 5/17/60). The other two subjects in group IIB subsequently died in hepatic coma and with azotemia.

Post-metaraminol periods. The blood pressure of all but two subjects fell to levels similar to, or below those of the pre-metaraminol periods within 5 to 30 minutes after the administration of the drug was stopped. The blood pressure of W.F. and J.K. fell to those levels within 90 minutes. As depicted in Figures 2, 3, and 4 there was a very prompt decline in the rates of urine flow, and the excretion of total solute, sodium, and potassium after the metaraminol infusion was terminated. In fact, urinary excretion of fluid and electrolytes generally reached levels comparable with or below those of the pre-metaraminol periods within 30 minutes after discontinuing the drug, except in the two whose blood pressure remained elevated. 


\section{Intramuscular and oral metaraminol}

Patient E.A., with cirrhosis, jaundice, and ascites, was given $7 \mathrm{mg}$ of metaraminol intramuscularly at the height of water diuresis. The details of this study are depicted in Figure 5, demonstrating the temporal relationships of a single intramuscular dose of drug to changes in blood pressure and renal excretion.

Patient I.W. was given $25 \mathrm{mg}$ of metaraminol by mouth. Within less than 30 minutes there was an increase in blood pressure; within 60 minutes there was a change in renal excretion, the peak being attained within 100 minutes with a rise in urine flow from 4.7 to $8.7 \mathrm{ml}$ per minute; an increase in sodium excretion from 4 to $71 \mu \mathrm{Eq}$ per minute; a rise in potassium from 19 to 56 $\mu \mathrm{Eq}$ per minute; and an increase in total solute excretion from 199 to $418 \mu$ Osm per minute.
Within 130 minutes from the time the drug was given, return to control values for blood pressure and urinary excretion was noted.

\section{DISCUSSION}

The study demonstrates that metaraminol generally produces increased excretion of water, sodium, potassium, and total solute in patients with Laennec's cirrhosis. These changes are observed in patients with good diuretic response to administered water and normal GFR (group I) and in patients with limitation in water diuresis and normal or slightly reduced GFR (group IIA). Subjects with limited water diuresis and marked reduction in GFR (group IIB) manifest smaller changes. Administration of the drug did not produce comparable effects in subjects without liver disease.

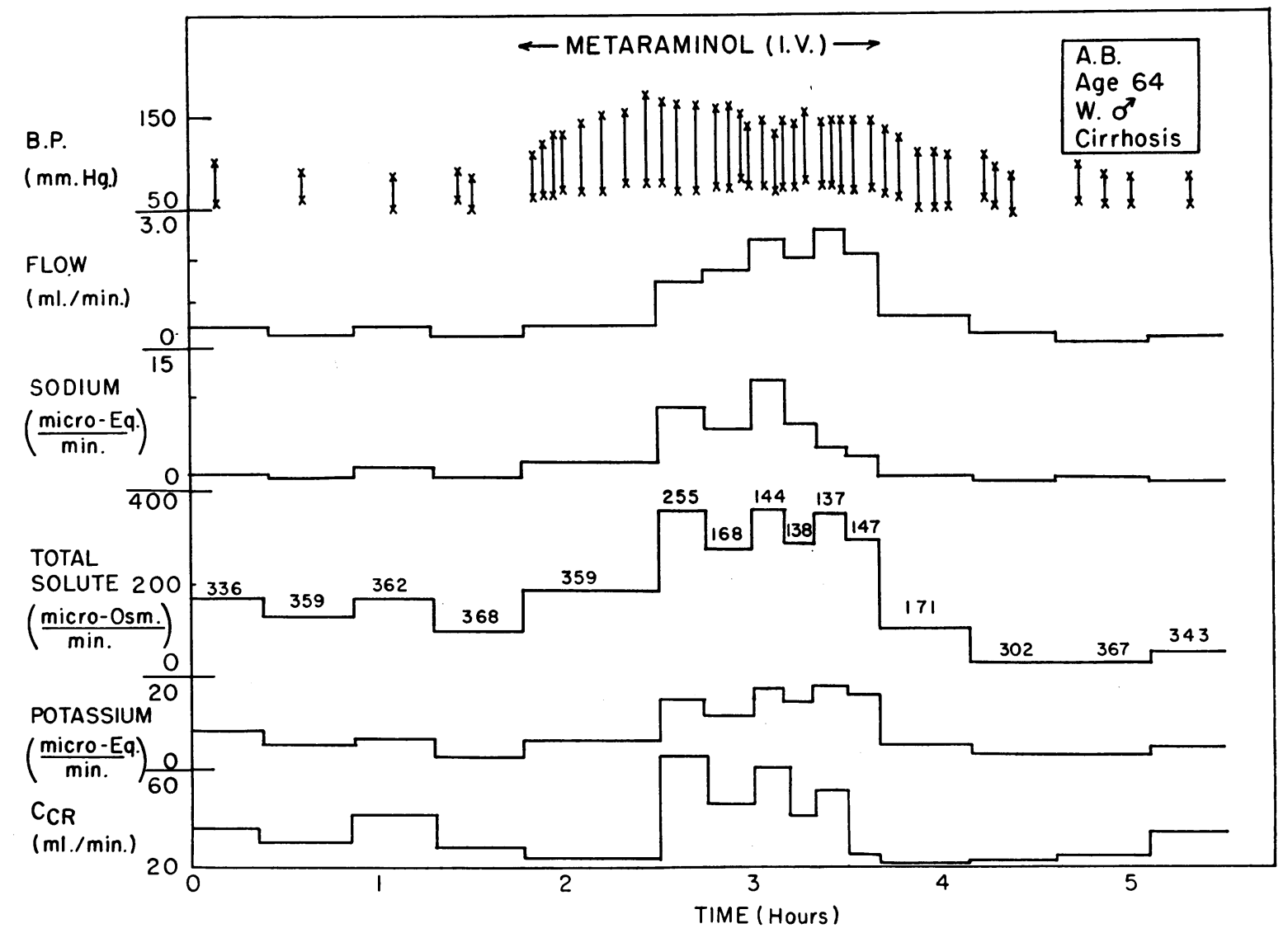

Fig. 4. Infusion of metaraminol in patient with CIRRhosis, group irb (A.B.). Note that ordinate scale differs from other figures. The number above total solute excretion denotes the urine concentration in $\mathrm{mOsm}$ per $\mathrm{kg}$ of water for each period. 
The manner in which metaraminol affects water and solute excretion is not known. The fact that the observed changes are associated with elevation of blood pressure, and reverse promptly with withdrawal of a drug known to act upon the circulation, suggests a circulatory mediation. However, such a mechanism may not account for the 35 to 40 minute delay apparent in renal effect after the infusion was begun, irrespective of whether blood pressure was raised rapidly (5 minutes) or slowly (30 minutes). At any rate, if the drug effect is mediated via altered circulation, the exact nature of the circulatory changes and how the kidney participates remain obscure.

It is entirely possible that the observed changes in solute and water excretion during drug administration are related to direct action of metaraminol upon the renal circulation. Thus, a primary increase in glomerular filtration rate could account for the observed changes despite the fact that an increased GFR was not consistently observed. It may well be that significant but undetected increments in GFR occurred. Certain observations in the dog suggest caution in the interpretation of the role of altered GFR in the mediation of the effects of metaraminol. Large doses of the drug in the dog have been accompanied by reduction in GFR with concomitant increase in the excretion of sodium, indicating a tubular site of action (14). In the present studies, however, increased water excretion rather than sodium is the prominent feature. It is possible that metaraminol may have a direct action on the renal circulation not necessarily reflected in the rate of glomerular filtration. A variety of alterations in distribution of the intrarenal circulation could play a part in the observed changes. These factors are not clearly known in the normal situation and consequently cannot yet be defined under abnormal conditions.

If metaraminol exerts its effect via alterations in the circulation, the primary site of action might be extrarenal, with the kidney influenced only indirectly. That blood is not distributed normally in certain patients with cirrhosis is apparent from the development of collateral circulation to the portal vein and the presence of peripheral vascular dilatation, a situation analagous to multiple arteriovenous shunts $(15,16)$. If metaraminol, by its vasopressor action, closes "shunts" and

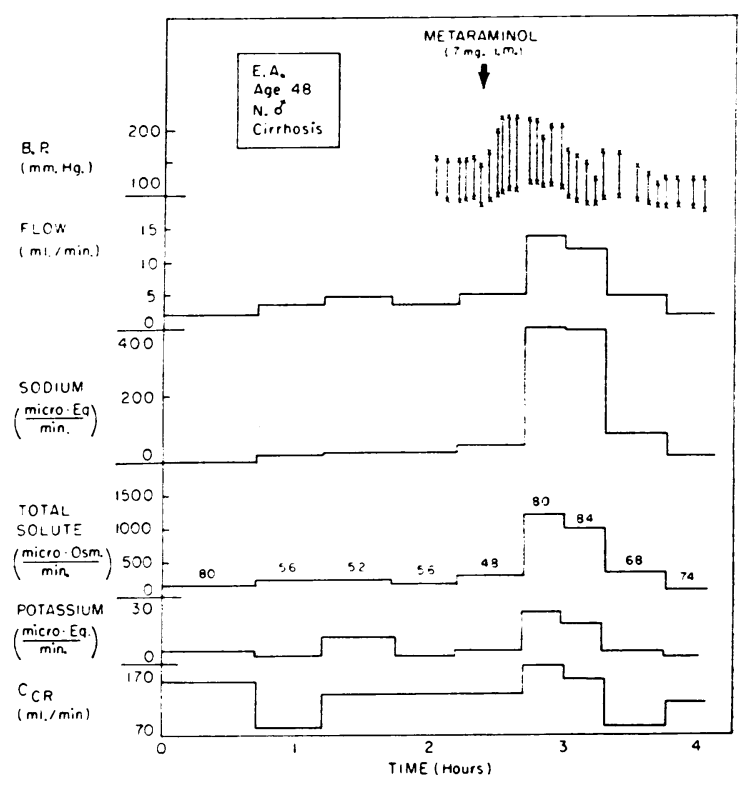

Fig. 5. Intramuscular injection of metaraminol in a PATIENT With CirRhosis (E.A.). Note that ordinate scale differs from other figures. The number above total solute excretion denotes the urine concentration in mOsm per $\mathrm{kg}$ of water for each period.

results in a more normal distribution of blood, this may make more blood available to the kidney with resultant increase in GFR (or perhaps other less well defined alterations in intrarenal circulation). The present data on renal blood flow may be too few to allow for any conclusion, but it appears that renal blood flow is not consistently increased after drug administration, since there is not a consistent increase in the clearance of $\mathrm{PAH}$, and the clearance of $\mathrm{PAH}$ may be a minimal figure for renal perfusion under any circumstances rather than a true measure of renal plasma flow (10b).

Metaraminol may have its effect directly on the proximal tubular cells, diminishing sodium reabsorption. A decrease in sodium reabsorption might then lead to solute diuresis. This type of diuresis in subjects with a dilute urine is characterized by increase in urine flow, solute excretion, and a slight increase in osmolality. This was found in the subjects of group I. But metaraminol did not produce a simple solute diuresis in the subjects of group II who began with concentrated urine. In a typical solute diuresis with initially concentrated urine, urine osmolality approaches but is not reduced below that of plasma 
except for occasional very high osmolar clearances. In the subjects of group IIA, however, urine osmolality decreased below that of plasma. Thus if one postulates that metaraminol acts by way of diminishing proximal tubular reabsorption of sodium, one must also postulate that distal tubular reabsorption of sodium is not similarly effected. Nonetheless, it is entirely reasonable to state that the effects of metaraminol upon water and electrolyte excretion observed in this study might just as well have been attributed to proximal tubular effects as to changes in GFR.

We have already indicated that metaraminol may have an extrarenal effect resulting in altered distribution of blood and augmented renal perfusion. Similarly, one may reason that such altered distribution may effect a "volume" receptor mechanism resulting in decreased tubular reabsorption of sodium and water $(17,18)$. Such a mechanism would fail to account for the observed increase in potassium excretion and for the prominence of the effect on water rather than sodium excretion.

Metaraminol may act by the inhibition of antidiuretic hormone (ADH), but such a phenomenon could not explain all of the observed results. First, the effects on potassium and sodium excretion that were observed could not be attributed to ADH. Second, ADH levels were presumed minimal or absent in the subjects of group I who had low urine osmolalities and large urine flows in response to water loading. Nevertheless, metaraminol was still able to effect a considerable increase in water and solute excretion in these subjects.

It is of interest to compare the patients in group IIA with those in IIB in order to determine why the former responded so well to metaraminol while the latter had limited response. Urine flow was reduced, the urine was concentrated, and there was impairment of sodium excretion in both groups. The major differences between the two seem to be in the quantitative reduction in filtration rate and the slightly lower blood pressure in IIB subjects before drug administration.

Our experience with metaraminol includes observations not previously reported in the literature. One of our patients with cirrhosis died abruptly, manifesting ventricular fibrillation on an electrocardiogram taken terminally. This man had been receiving the drug by intravenous infusion for 100 minutes in rate and quantity and with blood pressure elevation entirely comparable with that of the other subjects of this report. No specific cause of death was established at autopsy. In subsequent studies ventricular extrasystoles were noted on the electrocardiograms of several patients with cirrhosis and one subject without liver disease; these promptly subsided upon reducing the rate of metaraminol infusion.

\section{SUMMARY}

Patients with Laennec's cirrhosis and ascites and subjects without liver disease were given metaraminol, a synthetic sympathomimetic amine, during the course of sustained water diuresis. In patients with Laennec's cirrhosis and a response to administered water, the infusion of metaraminol generally resulted in augmentation of water diuresis and increased excretion of sodium, potassium, and total solute. Most of the patients with cirrhosis and impaired response to water loading developed an increase in water excretion and the rate of solute excretion after the administration of the drug. Several patients with cirrhosis and impaired response to water loading accompanied by extremely low glomerular filtration rate exhibited much less response to metaraminol.

Subjects without liver disease did not exhibit similar changes. The mechanism of action of metaraminol in this study was uncertain, but a most likely explanation involves alteration in circulatory phenomena. The specific mechanism of such alterations is not clear. All of the data are consistent with an increase in the rate of glomerular filtration alone, although with conventional techniques such increment was not consistently observed after the administration of the drug. A direct action of the drug upon the proximal tubular cells cannot be excluded.

One of the patients died during administration of the metaraminol. A terminal electrocardiogram showed ventricular fibrillation.

\section{ACKNOWLEDGMENTS}

The authors are grateful to Dr. Maurice B. Strauss for his advice, and to Misses Elsie C. Rossmeisl, Helen Alpert, Miriam Halpin, Regina McLean, and Ellen Vaznelis for their technical assistance. 


\section{REFERENCES}

1. Papper, S. The role of the kidney in Laennec's cirrhosis of the liver. Medicine (Baltimore) 1958, 37, 299.

2. Papper, S., Belsky, J. L., and Bleifer, K. H. Renal failure in Laennec's cirrhosis of the liver. I. Description of clinical and laboratory features. Ann. intern. Med. 1959, 51, 759.

3. Hecker, R., and Sherlock, S. Electrolyte and circulatory changes in terminal liver failure. Lancet 1956, 271, 1121.

4. Lancestremere, R. G., Davidson, P. L., Earley, L. E., O'Brien, F. J., and Papper, S. Unpublished observations.

5. Murray, J. F., Dawson, A. M., and Sherlock, S. Circulatory changes in chronic liver disease. Amer. J. Med. 1958, 24, 358.

6. Peters, J. H. The determination of creatinine and creatine in blood and urine with the photoelectric colorimeter. J. biol. Chem. 1942, 146, 179.

7. Hare, R. S. Endogenous creatinine in serum and urine. Proc. Soc. exp. Biol. (N. Y.) 1950, 74, 148.

8. Young, M. K., Jr., and Raisz, L. G. An anthrone procedure for determination of inulin in biological fluids. Proc. Soc. exp. Biol. (N. Y.) 1952, 80, 771.

9. Goldring, W., and Chasis, H. Hypertension and Hypertensive Disease. New York, Commonwealth Fund, 1944, p. 203.
10. Smith, H. W. The Kidney. New York, Oxford Univ. Press, 1951 ; a) p. 39 ; b) p. 162.

11. Rosenbaum, J. D., Nelson, W. P., III, Strauss, M. B., Davis, R. K., and Rossmeisl, E. C. Variation in the diuretic response to ingested water related to the renal excretion of solutes. J. clin. Invest. 1953, 32, 394.

12. Kleeman, C. R., Epstein, F. H., and White, C. The effect of variations in solute excretion and glomerular filtration on water diuresis. J. clin. Invest. 1956, 35, 749.

13. Papper, S., and Saxon, L. The diuretic response to administered water in patients with liver disease. II : Laennec's cirrhosis of the liver. A.M.A. Arch. intern. Med. 1959, 103, 750.

14. Moyer, J. H., and Handley, C. A. Blood pressure and renal hemodynamic responses to aramine and the alterations of these responses by adrenergic blockade with dibenzyline. Amer. Heart J. 1954, 48, 173.

15. McIndoe, A. H. Vascular lesions of portal cirrhosis. Arch. Path. (Chicago) 1928, 5, 23.

16. Abelmann, W. H., Kowalski, H. J., and McNeely, W. F. The hemodynamic response to exercise in patients with Laennec's cirrhosis. J. clin. Invest. 1955, 34, 690.

17. Epstein, F. H. Renal excretion of sodium and the concept of a volume receptor. Yale J. Biol. Med. 1957, 29, 282.

18. Welt, L. G. Volume receptors. Circulation 1960, 21, 1002. 